\title{
Family prospects of the Russian youth in conditions of social change
}

\author{
Elena Ippolitova ${ }^{1}$, Irina Ralnikova ${ }^{1, *}$, and Olga Gurova ${ }^{1}$ \\ ${ }^{1}$ Altai State University, 656049, 61a Lenina ave., Barnaul, Russia.
}

\begin{abstract}
The article presents the results of a study of the family prospects of modern youth for the period from 2011 to 2017. A tendency has been revealed to reorient young people from traditional family values, including the birth and upbringing of children, to creating a satisfying need for support, freedom, and self-development of the partnership. There is a reduction in the target saturation of family prospects for young people, the reduction in the content of their goals related to marital relations, while concentrating on the planning of personal development. The family prospects of Russian youth reflect their focus on creating in the future not a traditional patriarchal family, but a free alliance that implements emotional, psychological, as well as recreational functions and a safety function at the expense of the reproductive one.
\end{abstract}

\section{Introduction}

Modernization of the contemporary Russian society affects various areas of its functioning. Intensive changes systematically cover the scope of family and marriage (S. I. Golod, T. A. Gurko, S. V. Darmodekhin, L. V. Kartseva) [1, 2, 3]. A new model of the family, which is reflected in the public consciousness and is fixed in mass behavior, corresponds today to the changed society. The scale of the transformations that are characteristic of the modern family allows us to speak about the crisis of this institution of socialization, which objectifies itself in changing the structure and functions of the family, changing the nature of its relationships with other social institutions, the transition of family and marriage models from traditional ("patriarchal") to progressive modern types [4].

The family at the moment is a dynamic institution, which is less regulated by social factors. Along with this, changes in the political, economic, educational and other spheres of society have a more destabilizing effect on it. In addition, there is a high rate of functional and structural changes in a modern family that take place during the lifetime of one or two generations. In this situation, the process of transformation of family values and their adaptation to new living conditions often occurs with the active participation of young people [5].

\section{Dynamic changes in the family institution}

\footnotetext{
* Corresponding author: irinaralnikova @ yandex.ru
} 
The scale and dynamism of family changes in the contemporary world contribute to the emergence of a special freedom of self-realization of the individual in the family sphere that is not characteristic of previous eras. Among such freedoms, we consider the following: liberalization of sexual norms, the choice of a mate, the time of the birth of children and their number, methods of family education, the level of education of children, the distribution of household duties among family members, forms of joint leisure activities, etc. Today, the transformations of the institution of family and marriage are manifested in the variability of the forms of sexual and marital-family relations, in the increased instability of the family structure, and in the change in the functional side.

As an alternative to the traditional form of marital relations, trial, guest, and seasonal marriages, free unions, prisoners, including between the same sex, are considered. The structure of the family becomes more mobile, which is associated with an increase in the number of divorces, foster families, extramarital births, the prevalence of families of repeated marriages $[1,6]$.

The changes of the contemporary family are also seen by researchers in the fact that it turns into a partnership group from a socially regulated union, where relationships are built on the basis of accepting the uniqueness and independence of another person $[2,7]$. The leading socio-psychological functions of the modern family are emotional, psychological, and recreational ones; the purpose of which, in general, implies creating conditions for the socio-psychological and mental development of its members [7].

Changes in the family institution of the family in the contemporary world make it possible to comprehend the process of family-marriage self-determination of young people as containing a high degree of uncertainty, proceeding practically without reliance on stable landmarks, in the context of an endless variety of development options. This contributes to the emergence of the freedom of an individual's self-realization in the family sphere, which is not characteristic for the previous stages of social development, which implies the reduction of social restrictions on the choice of the marriage partner, the adoption of a decision on the form of marriage relations, their creation or dissolution, the birth and upbringing of children. In this situation, individual opportunities for self-realization in the family sphere expand, but people's readiness for independence and taking responsibility for their choices, as well as the ability to build consistent and realistic family prospects for him, are of particular importance.

Reformatting the institution of family and marriage at the present stage of development of the Russian society serves as a basis for understanding the new relevance of scientific research on the problem of family prospects. This relevance is seen in the need to fix the process of transforming the youths' ideas about their future in the sphere of family and marriage, taking place within the last decade, to reveal a new content of family prospects, and to forecast the trajectories of development of marital unions in Russia in the future. Particular attention in the study of this problem area is given to the youth as the age cohort most acceptable to social changes, simultaneously entering the period of creation of one's own family and the birth of children.

At the present stage of the development of Psychological Science, the issue of family perspectives is a field of study of the generalized human concepts about the future, being concretized in the aspect of studying the prospects for its self-realization in the family sphere. Relying on the scientific views of K. A. Abulkhanova-Slavskoy, E. I. Golovakhi, and A. A. Kronika, family perspectives can be defined as a person's ideas about the future of family life, mediating the search and selection of a mate, the reproduction of a certain style of conjugal and child-parent relationships $[8,9]$. Family prospects are considered as a vector of self-realization of an individual in the sphere of family and marital relations. In the basis of building the future in this sphere are the value-semantic reference points of an 
individual. Values, personal meanings, and goals set the prototype of the future, organize person's activities in the present in order to achieve the desired future $[10,11]$.

\section{Materials and methods}

We undertook an investigation into the transformation of the value/semantic coordinates and goals of young Russians in the sphere of family and marital relations. For this purpose, three diagnostic cuts were taken in 2011, 2014, 2017. The following methods were used: "The ratio of the 'value' and 'accessibility' of various life spheres" (E. B. Fantalova), the psychotechnical instrument of life choice called "Persoplan" (A. G. Shmelev). These tools, originally aimed at the study of the value-semantic orientations of individuals and the holistic image of a future person, were modified by the authors to focus on the content of family prospects. The method of mathematical-statistical data processing was the analysis of variance, performed with the help of computer statistical package "SPSS" 22.0. The total of 793 university students from different cities of Russia (Barnaul, Moscow, Novosibirsk, Perm, St. Petersburg, Chelyabinsk) took part in the research on a voluntary basis, being in the age of 18 to 21 years. In 2011, 267 people were surveyed (132 boys and 135 girls), in 2014 were 266 people (125 boys and 141 girls), and 260 people were questioned in 2017 (127 boys and 133 girls).

\section{Results and discussion}

Let's consider the results of the study on the value-semantic content of those family prospects that modern young people have. Analyzing the hierarchy of family values in the groups of respondents being interviewed in 2011, 2014, and 2017, it can be noted that such value as "loyalty," "trust," "freedom as independence in deeds and actions" increase every year. In contrast, the orientation towards "love," "birth," and "upbringing of children" decreases. Also, the availability of sexual gratification and diverse pastime increase. The values of "children" and "love" become less accessible compared to the group of respondents in 2011.

As a result of applying the variance analysis, reliable differences were established between representatives of three groups of respondents according to the rating of the importance of family values: "freedom as independence in deeds and actions" $(p=0.029)$, "children" ( $p=0.0001)$, and the availability of such values as "love" $(p=0,007)$, "community of interests" ( $p=0,016)$, and "children" $(p=0,0001)$. Every year, young people increasingly appreciate the preservation of personal freedom and devalues the birth and upbringing of children in a future family. There is a value-and-meaning restructuring that determines the face of family prospects, which is building a family union based on mutual respect for personal borders and the interests of partners, preserving the freedom of choice in the family.

Today, it is important for young people to maintain the psychotherapeutic and recreational functions of the family, the realization of which assumes the formation of conditions for the development and self-expression of each of its members. At the same time, young people, probably, see the preservation of their freedom in the future family life in refusing to give birth to children or postponing this event for a later period. With regard to the availability of family values, it is important to note that a diversified pastime in a family seems to be more achievable than love. These results can show the specificity of the choice of a marriage partner by modern young people, increasingly focused on finding a person with whom it could be interesting to spend time and have fun. And love is probably seen as a temporary and unstable phenomenon, along with a more stable mutual interest of 
partners. Thus, the modern youth is committed to building partnerships in families as opposed to traditional marital relations.

According to the data analyzed, among the representatives of the youth groups being surveyed, the most common goal in the marriage and family sphere is the birth of a child, which, however, is postponed for a fairly long time. Respondents of 2017 think of achieving financial stability, self-development within the family and abroad, and building a career as important goals. The construction of satisfying family relationships and civil marriage are less important for them. Against this background, the young people surveyed in 2014 listed the goals related to having an official marriage, career building, and the acquisition of their own housing as top priority. Less important were the planning of selfdevelopment and being officially married.

It is established that the number of goals lying in the sphere of marital-family relations significantly reduces for the young people every year $(p=0.0001)$. Observing a reduction in the number of such goals, the arsenal of possible means of achieving them narrowed $(p=$ 0.0001 ). Along with this, the number of obstacles on the way to achieving the goals is also significantly reduced $(p=0.001)$. With regard to the orientation of the goals in the sphere of family and marital relations, it can be noted that young people are less likely to enter into official marriage $(p=.017)$ and enter into a civil marriage $(p=0.041)$. Priorities are the goals associated with the development of their own personalities $(p=0.004)$.

\section{Conclusion}

Thus, on the basis of the conducted research, it can be concluded that there is an intensive transformation of the family prospects of the youth in the aspects of their value-semantic bases and goal-setting under the conditions of social changes. Every year, young people increasingly appreciate the preservation of personal freedom, trust in a partner, and loyalty to a future family. At the same time, the guidelines for childbearing are weakening. In the extension of the period of childlessness, modern young people see the possibility of maintaining independence in the family. They are not ready to face the "family routine" associated with the standard implementation of conjugal and parental roles. This emphasizes the growing importance of the recreational function of the family, the function of rest, active, and rich pastime. In the rapidly changing world, the youth view marriage as being based on the recognition of the importance of their own needs as opposed to the norms and requirements of the society. The family as a social institution remains attractive to young Russians, while the reorientation to new forms of family relations is becoming more actual.

\section{Acknowledgements}

The research was supported by the Russian Foundation for Basic Research, Project 17-3600023-OGN "Human Life Perspectives in a Changing World" (Rossiyskiy fond fundamentalnykh issledovaniy, proyekt 17-36-00023-OGN "Zhiznennyye perspektivy cheloveka v izmenyayushchemsya mire").

\section{References}

1. S. I. Golod, Zhurnal Sotsiologii i Sotsialnoy Antropologii, 2 (2012)

2. T. A. Gurko, Sotsiologicheskiye issledovaniya, 11 (2017)

3. S. V. Darmodekhin, Mir Psikhologii, 3 (2008) 
4. S. I. Golod, Sotsiologicheskiye issledovaniya, 1 (2008)

5. L. V. Kartseva, Gumanitarnyye nauki v XXI veke: nauchnyy Internet-zhurnal, 9, (2017)

6. Yu. P. Lezhnina, Sotsiologicheskaya nauka i sotsialnaya praktika, 2 (2016)

7. V. V. Ryabova, Problemy sotsialno-ekonomicheskogo razvitiya Sibiri, 3, (2014)

8. K. A. Abulkhanova-Slavskaya, T. N. Berezina, Personality time and time of life (Aleteya, Sankt-Peterburg, 2001)

9. Ye. A. Golovakha, A. A. Kronik, Psychological time of personality (Smysl Moskva, 2008)

10. I. A. Ralnikova, E. A. Ippolitova, O. S. Gurova, L. D. Demina, M. A. Kostenko, Asian Social Science, 11, 19 (2015)

11. Ye. A. Ippolitova, Family prospects of the youth in the changing world (Azbuka, Barnaul, 2012) 